\title{
Konsumerisme terhadap Gawai dan Dampaknya bagi Lingkungan: Studi Kasus pada Apple Inc.
}

\author{
Yanuar Albertus \\ Universitas Airlangga
}

\begin{abstract}
ABSTRAK
Tulisan ini membahas mengenai bagaimana dampak konsumerisme gawai bagi kelestarian lingkungan. Konsumsi gawai dalam kurun waktu beberapa tahun terakhir meningkat tajam. Hal ini dibuktikan dengan masifnya penggunaan peranti teknologi oleh masyarakat dunia secara keseluruhan. Fenomena ini mengarah pada apa yang disebut dengan konsumerisme, yakni suatu kondisi masyarakat yang di dalamnya konsumsi tidak lagi dilakukan untuk memenuhi kebutuhan, tetapi justru menjadi tujuan dan gaya hidup. Argumen penulis adalah bahwa konsumerismeterhadap perantiteknologimembawa ancamanyang serius bagi kelestarian lingkungan, khususnya terkait dua hal, yakni eksploitasi sumber daya yang semakin intensif serta limbah elektronik yang dapat mencemari lingkungan. Analisis dilakukan dengan menggunakan studi literatur dan untuk memperkuat argumen penulis, tulisan ini juga mengangkat studi kasus fenomena konsumerisme terhadap produk Apple Inc. sebagai perusahaan teknologi terbesar di dunia, khususnya iPhone yang menjadi produk utama dari perusahaan tersebut.
\end{abstract}

Kata-kata Kunci: Apple Inc., Gawai, Konsumerisme, Konsumsi, Lingkungan

This paper discusses how consumerism on technological devices could affect environmental sustainability. Consumption of technological devices in the past few years has risen sharply. This could be proven by the massive use of technological devices by the world community as a whole. This phenomenon leads to what is called consumerism, which refers to a condition of society in which consumption is no longer made to meet needs, but instead becomes a life goal and lifestyle. The author argues that consumerism on technological devices poses a serious threat to environmental sustainability, specifically related to two things, namely the intensification on resource exploitation and the culmination of electronic waste that can pollute the environment. The analysis was carried out using literature studies and to strengthen the writer's argument, this paper also raised a case study of the phenomenon of consumerism on Apple Inc. products, especially the iPhone which has become the main product of the company.

Keywords: Apple Inc., Technological Devices, Consumerism, Consumption, Environment 
Gawai dapat dikatakan sebagai salah satu barang yang penting di abad ke-21. Argumen ini tidak berlebihan dengan adanya fakta bahwa gawai telah menjadi bagian dari kehidupan sehari-hari manusia di berbagai wilayah di dunia. Di Finlandia misalnya, hasil riset menunjukkan bahwa telepon seluler, serta peranti teknologi informasi dan komunikasi lainnya telah menjadi hal yang tidak terpisahkan bagi kehidupan sehari-hari masyarakatnya. Pada tahun 2002, sekitar 92\% dari seluruh keluarga yang ada di Finlandia memiliki setidaknya satu buah ponsel. Sebagian besar dari keluargakeluarga tersebut, pada tahun 2001, mempunyai ponsel sebanyak anggota keluarga yang berusia di atas sepuluh tahun (Kuure 2003; Statistics Finland 2001 dalam Wilska 2003). Lebih lanjut, data yang dikeluarkan oleh Eurobarometer pada tahun 2001 (dalam Wilska 2003) menunjukkan bahwa 93\% pemuda Finlandia yang berusia 15-24 menggunakan ponsel secara teratur setiap harinya. Fenomena serupa juga dijumpai di negara-negara Eropa lainnya, seperti di Swedia, yang besarannya mencapai 90\%. (Kuure 2003 dalam Wilska 2003). Fenomena maraknya penggunaan peranti teknologi tidak hanya terjadi di Eropa, tetapi juga di negara-negara berkembang. Di India, adopsi ponsel dalam keluarga bertumbuh cukup pesat dari hanya 15\% pada tahun 1998 menjadi 95\% pada tahun 2008. Konsumsi komputer ataupun laptop dalam keluarga di masyarakat India juga meningkat tajam dari 17,6\% menjadi $80 \%$ dalam periode yang sama (Mitra 2008 dalam Thomas dan Wilson 2012).

Adopsi gawai yang cukup masif kemudian berimplikasi pada kecenderungan perilaku konsumtif di masyarakat atau yang lebih dikenal sebagai konsumerisme. Konsumerisme merupakan konsep yang digunakan untuk menggambarkan kondisi dalam masyarakat yang sebagian besar mendefinisikan tujuan hidupnya untuk mendapatkan barang yang sesungguhnya tidak mereka perlukan secara substansial. Masyarakat tersebut menjadi terikat dengan proses akuisisi atau proses belanja itu sendiri dan bahkan mendefinisikan identitasnya dari barang-barang yang dibeli dan digunakan (Stearns 2006). Fenomena konsumerisme ini dapat ditunjukkan salah satunya dari seringnya konsumen mengganti gawai yang dimilikinya. Lu (2017) menyatakan bahwa masyarakat di seluruh dunia rata-rata mengganti smartphone yang dimilikinya setiap 21 bulan sekali. Dengan kata lain, setiap kurang dari dua tahun sekali, orang akan cenderung membeli smartphone yang baru. Argumen ini juga didukung oleh hasil riset Kantar World Panel (dalam Dunn, 2017) yang menyatakan bahwa masyarakat baik di Eropa, Amerika Serikat, ataupun Tiongkok, cenderung memperbarui smartphone-nya kurang dari dua tahun sekali, yakni setiap 20-22 bulan sekali. Selain itu, muncul kecenderungan bahwa 
tindakan konsumsi yang dilakukan terhadap peranti teknologi tidak seluruhnya dilakukan sebagai pemenuhan kebutuhan hidup. Hal ini dapat dibuktikan, salah satunya melalui riset yang dilakukan oleh Rahmawati et al. (2018). Hasil riset tersebut menyatakan bahwa konsumsi gawai yang dilakukan oleh pemuda di Kota Kudus memang memenuhi kebutuhan akan teknologi komunikasi, namun sebagian dari pemuda tersebut mengonsumsi gawai hanya sebagai simbol dari identitas dan kebanggaan. Dalam kasus ini, penggunaan gawai seperti ponsel, laptop, tablet, dan lainnya dianggap dapat meningkatkan pamor dan status sosial penggunanya.

Masifnya adopsi peranti teknologi di masyarakat lantas membawa dampak tersendiri bagi dunia, salah satunya terkait lingkungan. Secara sederhana, konsumerisme menyebabkan kerusakan lingkungan dengan adanya eksploitasi sumber daya yang berlebihan serta potensi munculnya sampah dari aktivitas konsumsi berlebihan tersebut. Adapun tulisan ini membahas lebih lanjut mengenai bagaimana konsumerisme terhadap peranti teknologi dapat terbentuk serta dampaknya terhadap lingkungan. Argumen penulis adalah bahwa fenomena konsumerisme terhadap peranti teknologi terbentuk karena aktivitas korporasi yang semakin masif dalam menjual produk-produknya. Konsumerisme terhadap produk teknologi tersebut selanjutnya berpotensi untuk menyebabkan kerusakan lingkungan dengan mendorong adanya eksploitasi sumber daya serta meningkatnya limbah elektronik yang dihasilkan. Untuk menjelaskan argumen tersebut, tulisan ini dibagi ke dalam tiga bagian. Bagian pertama menjelaskan secara teoritik bagaimana fenomena konsumerisme dapat terbentuk dan dampaknya bagi lingkungan. Bagian kedua menjelaskan lebih lanjut argumen penulis melalui studi kasus terhadap Apple Inc. sebagai perusahaan teknologi terbesar di dunia. Sementara itu, bagian terakhir akan berisi kesimpulan yang didapat dari hasil analisis penulis.

\section{Konsumerisme dan Dampaknya bagi Lingkungan}

Sepertiyang telah dituliskan pada bagian sebelumnya, konsumerisme menggambarkan suatu masyarakat yang mempunyai kecenderungan untuk mendefinisikan tujuan hidupnya sebagai upaya memperoleh barang yang bukan menjadi kebutuhan hidupnya (Stearns 2006). Konsumerisme pada dasarnya bukanlah hal baru. Akar dari perilaku konsumtif yang ada di masyarakat modern saat ini dapat dijumpai dalam masyarakat agrikultural, salah satunya melalui keberadaan kaum aristokrat yang mempunyai kecenderungan untuk menikmati produk-produk mewah ataupun hal-hal baru. Kaum aristokrat bahkan mempunyai kecenderungan untuk mendefinisikan kelas 
mereka dengan gaya konsumsi yang mereka miliki. Fenomena konsumerisme serupa dapat dijumpai di Tiongkok tepatnya pada masa Dinasti Tang dengan adanya kelompok pedagang yang mulai bertumbuh dalam jumlah dan kekayaan. Kaum pedagang ini mendorong berkembangnya perilaku konsumtif di berbagai belahan dunia dengan melakukan penyebaran barang-barang ke seluruh dunia dan selanjutnyajuga mempunyai kecenderungan untuk meniru gaya hidup kaum Aristokrat yang ditemuinya. Namun demikian, fenomena konsumerisme masih terbatas pada kaum-kaum tertentu karena adanya hambatan dalam penyebaran kecenderungan konsumtif di masyarakat, tepatnya hambatan yang disebabkan oleh kemiskinan (Stearns 2006). Hal inilah yang kemudian membedakan fenomena konsumerisme dalam masyarakat agrikutural dengan konsumerisme dalam masyarakat modern saat ini yang cenderung melintasi batas kelas sosial atau bahkan justru menyebabkan batasbatas kelas sosial itu sendiri memudar.

Stearns (2006) menjelaskan lebih lanjut bagaimana konsumerisme terbentuk dalam masyarakat modern sejak abad ke-18. Awalnya, terdapat argumen bahwa konsumerisme muncul sebagai sifat dasar manusia, namun argumen tersebut dinilai over-simplistic. Stearns (2006) mengidentifikasi beberapa faktor lain yang mendorong berkembangnya konsumerisme di masyarakat, seperti meningkatnya kesejahteraan, hingga paparan terhadap produk dan mekanisme pemasaran yang baru. Keterlibatan bangsa-bangsa Eropa dalam perdagangan bebas telah memungkinkan adanya produk-produk baru yang beredar dalam masyarakat yang juga disertai dengan upaya pemasaran untuk meningkatkan penjualan produk-produk tersebut. Peningkatan dalam kesejahteraan masyarakat menjadi pre-kondisi yang mendukung masyarakat untuk membeli produkproduk baru tersebut. Kondisi ini didukung pula oleh berbagai perubahan dalam masyarakat, baik sifatnya kultural maupun sosial seperti adanya enlightenment yang mendorong perkembangan sekularisme, adanya komersialisasi dalam masyarakat yang memungkinkan masyarakat untuk mencapai kesejahteraan dengan berbagai cara, hingga adanya relasi gender dengan upaya berbagai iklan yang menyasar kaum perempuan sebagai pihak mengontrol keuangan dan belanja keluarga (Stearns 2006). Faktor-faktor inilah yang kemudian memicu perkembangan konsumerisme dalam masyarakat secara luas pasca abad ke-18.

Konsumerisme kemudian menjadi fenomena global seiring dengan berjalannya waktu. Dalam konteks ini, globalisasi mempunyai peran tersendiri yakni dengan memungkinkan arus ataupun pergerakan manusia, barang, dan jasa yang lebih besar dan mengarah pada 
meningkatnya integrasi dan inter-konektivitas antara wilayahwilayah di dunia (Ritzer 2007). Globalisasi telah memungkinkan sebuah barang untuk tersebar secara luas di berbagai dunia, sedangkan masyarakat dunia juga dapat berkunjung dari satu tempat ke tempat lainnya sehingga dapat menemukan hal-hal baru yang menarik untuk dikonsumsi. Lebih lanjut, globalisasi juga memungkinkan untuk bertumbuhnya korporasi-korporasi multinasional yang dapat beroperasi secara lintas batas. Thun (2008) menyatakan bahwa globalisasi saat ini telah menciptakan berbagai kemungkinan yang belum pernah terjadi sebelumnya bagi korporasi untuk mengatur kembali dan merelokasi kegiatan mereka di seluruh dunia. Salah satunya ditunjukkan dalam global value chains sebagai bentuk pengorganisasian proses produksi secara internasional di mana setiap tahapan berbeda dalam proses produksi dilakukan pada lokasi-lokasi berbeda di beragam negara di dunia (OECD n.d.). Global value chain memungkinkan perusahaan untuk membagi proses produksi di berbagai belahan dunia. Fragmentasi ini dapat meningkatkan produktivitas perusahaan maupun menekan biaya produksi sehingga produk-produk yang dihasilkan menjadi lebih terjangkau bagi masyarakat. Sebagai akibatnya, aksesibilitas produk oleh masyarakat menjadi semakin mudah sehingga dapat mendorong tindakan konsumtif. Tidak hanya itu, global value chain juga memberikan potensi untuk semakin meningkatnya kesejahteraan di berbagai belahan dunia. Anabel Gonzalez (dalam World Bank 2018) selaku Direktur Senior World Bank Group's Trade \& Competitiveness Global Practice menyatakan bahwa:

"Global value chains are helping to advance the development process in many countries, including developing countries where they contribute to increased productivity, more international trade and faster growth, all of which benefit entire populations.” (Gonzales dalam World Bank 2018).

Peningkatan kesejahteraan ini telah mendorong berkembangnya consumption-oriented middle class disertai dengan pertumbuhan kota-kota dan industri di berbagai belahan dunia (Stearns 2006). Konsumerisme lantas berkembang secara luas di masyarakat dunia, bahkan dalam sudut pandang consumption-oriented terdapat premis bahwa ekonomi hanya akan maju dan sejahtera apabila masyarakat membeli lebih banyak produk dan membelanjakan uangnya untuk barang dan jasa (Thomas dan Wilson 2012).

Aktivitas korporasi multinasional secara langsung juga berperan dalam mendorong perkembangan konsumerisme di masyarakat, utamanya melalui aktivitas global branding. Peningkatan kesejahteraan masyarakat dunia telah mendorong korporasi-korporasi 
dunia untuk berkompetisi dalam mendapatkan pangsa pasar di kelas menengah yang terus berkembang. Branding kemudian menjadi strategi utama untuk tujuan tersebut, yakni dengan menciptakan loyalitas konsumen serta memperluas basis konsumen yang dimiliki oleh perusahaan. Brand yang dihasilkan adalah keseluruhan konstelasi antara makna, perasaan, persepsi, kepercayaan, hingga goodwill yang diatribusikan oleh konsumen kepada perusahaan terkait (Mumby 2012). Brand lantas menjadi nilai tersendiri yang dimiliki oleh perusahaan, yang mana nilai tersebut terkonstruksi dalam pemikiran seorang konsumen. Aktivitas branding lantas tidak hanya berhasil membentuk loyalitas konsumen, tetapi bahkan membentuk kebutuhan konsumen itu sendiri. Dalam konteks ini, konsumen tidak hanya dibujuk untuk memenuhi kebutuhan dan keinginan mereka, tetapi juga terus diyakinkan akan kebutuhan dan keinginan baru yang sebelumnya tidak mereka sadari. Lebih lanjut, konstruksi brand tersebut mampu menciptakan sebuah relasi emosional antara konsumen dan korporasi tersebut. Dalam kondisi demikian, produk itu sendiri menjadi kurang penting ketimbang image dan makna yang terasosiasi dalam produk tersebut (Mumby, 2012). Hal ini menyebabkan konsumsi yang dilakukan oleh konsumen bukan lagi dilakukan atas asas kegunaan tetapi justru pada konstruksi identitas diri yang memberikan kepuasan secara emosional. Fenomena ini salah satunya ditunjukkan dengan munculnya fanatisme di masyarakat terhadap brand tertentu. Konsekuensi dari pola konsumsi yang demikian adalah adanya perilaku untuk mempercepat pembuangan suatu produk dan pembelian produk yang baru sebagai akibat kecenderungan psikologis yang menilai bahwa suatu barang telah usang walaupun belum habis masa pakainya (Thomas dan Wilson 2012). Fenomena inilah yang kemudian mendorong terjadinya konsumerisme lebih lanjut di masyarakat dunia.

Fenomena konsumerisme dalam masyarakat tentu membawa berbagai dampak, termasuk di dalamnya adalah dampak terhadap lingkungan. Jelas bahwa konsumsi terhadap komoditas apa pun menyebabkan adanya penggunaan sumber daya (Morewedge et al., 2007; McKinnie 2017). Sejalan dengan hal itu, ketika konsumsi yang dilakukan oleh masyarakat dunia meningkat, maka manusia membutuhkan lebih banyak material dan energi. Sebagai akibatnya, aktivitas eksploitasi dan ekstraksi sumber daya menjadi lebih masif untuk memenuhi kebutuhan tersebut. Hal ini menjadi permasalahan tersendiri karena pada dasarnya cadangan sumber daya di bumi bersifat terbatas. Lebih lanjut, obsesi manusia untuk membeli barang dan jasa baru menimbulkan banyak sampah ataupun limbah di seluruh dunia (McKinnie 2017). Kondisi ini 
diperparah dengan adanya kecenderungan dari perusahaan untuk memproduksi barang dengan masa hidup yang pendek dengan kualitas yang lebih rendah. Sebagai akibatnya, terjadi peningkatan terhadap limbah di seluruh dunia. Lebih lanjut, analisis yang dilakukan oleh Orecchia dan Zoppoli (2007) memberkan kritik atas kurva Kuznetz. Argumen dalam kurva Kuznet menyatakan bahwa terdapat titik balik dalam hubungan antara peningkatan pendapatan dengan emisi karbon dioksida $\left(\mathrm{CO}_{2}\right)$. Pertumbuhan ekonomi pada mulanya akan menyebabkan peningkatan emisi $\mathrm{CO}_{2}$, namun dalam perkembangannya, peningkatan pendapatan akan mengembangkan kapasitas masyarakat untuk menciptakan sekaligus mengadopsi teknologi yang lebih ramah lingkungan sehingga emisi $\mathrm{CO}_{2}$ berangsur-angsur menurun. Namun, hasil analisis yang dilakukan oleh Orecchia dan Zoppoli (2007) menyatakan bahwa titik balik tersebut hanya terjadi di negara-negara maju. Titik balik tersebut dapat terjadi karena adanya environmental dumping yakni fenomena pemindahan industri-industri pencemar lingkungan ke negara-negara berkembang. Sebagai akibatnya, emisi $\mathrm{CO}_{2}$ di negaranegara maju dapat diturunkan, sedangkan emisi $\mathrm{CO}_{2}$ secara global tetap meningkat.

Dengan demikian dapat disimpulkan bahwa konsumerisme terbentuk seiring dengan peningkatan kesejahteraan disertai dengan aktivitas korporasi yang semakin masif dalam memperkenalkan produk-produk baru dan membentuk brand yang dimilikinya. Fenomena konsumerisme dalam masyarakat tersebut mempunyai dampak yang signifikan bagi lingkungan, setidaknya dalam dua hal yakni eskalasi dalam aktivitas eksploitasi dan ekstraksi sumber daya alam serta dengan meningkatnya limbah di seluruh dunia. Bagian selanjutnya akan membahas lebih spesifik mengenai bagaimana konsumerisme terhadap peranti teknologi dapat terbentuk dan dampaknya bagi lingkungan. Penjelasan dilakukan melalui studi kasus terhadap bagaimana konsumerisme terhadap produk Apple Inc. terbentuk serta potensi ancaman yang ditimbulkannya bagi lingkungan.

\section{Apple, Apple Fanboy, dan Sampah Elektronik}

Apple Inc. menjadi salah satu korporasi multinasional yang berkembang pesat di era globalisasi, bahkan pada tahun 2019, perusahaan ini dinobatkan oleh Forbes (2019) sebagai perusahaan teknologi terbesar di dunia. Apple Inc. didirikan pada tahun 1976 oleh kedua pendirinya yakni Steve Jobs dan Steve Wozniak dan saat ini telah berhasil mencatatkan pendapatan sebesar USD 262 milyar setiap tahunnya (Ponciano 2019). Perusahaan yang pada mulanya 
beroperasi di sebuah garasi milik Steve Jobs, saat ini telah beroperasi di berbagai belahan dunia dengan memperkerjakan sekitar 132.000 tenaga kerja. Pencapaian Apple Inc. sejatinya tidak berjalan mulus. Produk pertama Apple Inc. pada tahun 1976 yakni komputer Apple I sempat menuai penolakan dari Hewlett Packard (HP) sebagai perusahaan teknologi yang cukup besar pada masa itu. Kesuksesan Apple Inc. kemudian dimulai dengan diproduksinya Apple II pada tahun 1978. Produk ini berhasil dijual sebanyak 35.00o unit pada tahun 1979 dan angka tersebut meningkat menjadi 78.000 unit di tahun berikutnya (Johnson et al. 2012) berkat inovasi dalam produk Apple II. Apple II merevolusi industri komputer dengan memperkenalkan grafis warna untuk pertama kalinya. Penjualan pun melonjak dari USD 7,8 juta pada tahun 1978 menjadi USD 117 juta pada tahun 1980 (Richardson dan Terrell 2008). Kesuksesan ini berlanjut dengan diciptakannya Macintosh Computer yang dalam waktu singkat berhasil mencatatkan penjualan hingga 70.000 unit (Johnson et al. 2012). Kesuksesan Apple Inc. bertahan sampai tahun 1990-an hingga akhirnya pada tahun 1996 perusahaan ini mulai mengalami kemunduran, salah satunya disebabkan oleh adanya konflik internal yang menyebabkan kedua pendirinya keluar dari perusahaan tersebut. Wozniak meninggalkan Apple pada tahun 1983 diikuti Steve Jobs pada tahun 1985 (Richardson dan Terrell 2008).

Pasca mengalami kemunduran, Apple Inc. kembali bangkit setelah Jobs kembali ke Apple pada tahun 1997. Dapat dikatakan bahwa kembalinya Steve Jobs ke Apple menjadi titik balik Apple Inc. Pada tahun 1998, Apple Inc. berhasil merilis serta menjual produk iMac hingga mencapai angka 800 ribu unit (Johnson et al. 2012). Apple kemudian terus berinovasi dengan membuat produk-produk baru di luar komputer seperti iPod sebagai mp3 player yang dikenalkan pada tahun 2001, diikuti oleh telepon seluler bernama iPhone pada tahun 2007 dan tablet iPad pada tahun 2010. Tidak hanya di ranah hardware, Apple juga menciptakan software, salah satunya iTunes sebagai platform penjualan musik digital. Masing-masing dari produk Apple menuai kesuksesan. Pada tahun 2008, iTunes berhasil menjual lebih banyak musik apabila dibandingkan WalMart yang merupakan penyedia musik terkemuka pada saat itu. Sementara itu, iPod berhasil terjual hingga 275 juta unit antara tahun 2001 sampai tahun 2010 (Johnson et al. 2012). iPhone kemudian menjadi produk andalan Apple Inc. dengan menyumbang penjualan hingga mencapai 217,7 juta unit atau setara dengan USD 166,7 milyar pada tahun 2018. Dengan angka penjualan tersebut, iPhone menyumbang sebesar 63\% dari keseluruhan pendapatan Apple Inc. yang mencapai USD 265,6 milyar. Adapun data penjualan (dalam juta unit) dan 
pendapatan (dalam juta USD) Apple Inc dari tahun 2013 sampai tahun 2018 dapat dijumpai dalam tabel-tabel berikut.

Tabel 1. Pendapatan Apple Inc. Tahun 2013-2018

(dalam juta USD)

\begin{tabular}{|c|c|c|c|c|c|c|}
\hline $\begin{array}{c}\text { Pendapatan } \\
\text { Bersih }\end{array}$ & $\mathbf{2 0 1 8}$ & $\mathbf{2 0 1 7}$ & $\mathbf{2 0 1 6}$ & $\mathbf{2 0 1 5}$ & $\mathbf{2 0 1 4}$ & $\mathbf{2 0 1 3}$ \\
\hline iPhone & 166.699 & 141.319 & 136.700 & 155.041 & 101.991 & 91.279 \\
\hline iPad & 18.805 & 19.222 & 20.628 & 23.227 & 30.283 & 31.980 \\
\hline Mac & 25.484 & 25.850 & 22.831 & 25.471 & 24.079 & 21.483 \\
\hline Services & 37.190 & 29.980 & 24.348 & 19.909 & 18.063 & 16.051 \\
\hline Other Products & 17.417 & 12.863 & 11.132 & 10.067 & 8.379 & 10.117 \\
\hline Total Pendapatan & 265.595 & 229.234 & 215.639 & 233.715 & 182.795 & 170.910 \\
\hline
\end{tabular}

Sumber: Apple Inc. $(2015 ; 2018)$

Tabel 2. Penjualan Apple Inc. Tahun 2013-2018 (dalam ribuan unit)

\begin{tabular}{|l|c|c|c|c|c|r|}
\hline Penjualan Produk & $\mathbf{2 0 1 8}$ & $\mathbf{2 0 1 7}$ & $\mathbf{2 0 1 6}$ & $\mathbf{2 0 1 5}$ & $\mathbf{2 0 1 4}$ & \multicolumn{1}{c|}{$\mathbf{2 0 1 3}$} \\
\hline iPhone & 217.722 & 216.756 & 211.884 & 231.218 & 169.219 & 150.257 \\
\hline iPad & 43.535 & 43.753 & 45.590 & 54.856 & 67.977 & 71.033 \\
\hline Mac & 18.209 & 19.251 & 18.484 & 20.587 & 18.906 & 16.341 \\
\hline
\end{tabular}

Sumber: Apple Inc. $(2015 ; 2018)$

Dari kedua tabel di atas, dapat dilihat bahwa Apple setidaknya berhasil menjual lebih dari lebih dari 200 juta unit peranti teknologi yang terdiri dari iPhone, iPad, dan Mac. Data tersebut belum mencantumkan secara rinci peranti teknologi lainnya yang dimiliki Apple Inc. seperti Apple TV, Apple Watch, Beats Products, iPod, AirPods, dan lain sebagainya. Pangsa pasar iPhone sebagai produk utama Apple Inc. berhasil menempati tiga besar dunia pada tahun 2018. Data yang dilansir oleh Gartner (2019), sebuah lembaga riset, menunjukkan bahwa iPhone berhasil menguasai $15,8 \%$ pangsa pasar smartphone di dunia. Hal ini menunjukkan bagaimana konsumsi terhadap iPhone sebagai produk utama Apple Inc. cukup tinggi di masyarakat.

Maraknya penggunaan iPhone di masyarakat dunia dapat dikatakan sebagai bentuk konsumerisme di masyarakat. Hal ini ditunjukkan dengan keberadaan Apple Fans sebagai pengguna setia dari produk Apple Inc., khususnya iPhone. Keberadaan Apple Fans dapat dijumpai dalam setiap perilisan iPhone generasi baru. Setiap kali Apple Inc. merilis iPhone terbaru dapat dipastikan bahwa akan selalu 
ada orang yang mengantre untuk menjadi orang yang pertama kali membelinya. Hal ini terbukti seperti pada perilisan iPhone 11 tahun 2019. Berita yang dilansir oleh CNBC Indonesia menunjukkan bahwa fans Apple di Singapura telah membuat barisan antrian pada tanggal 19 September 2019, tepatnya sehari sebelum iPhone 11 secara resmi dijual. Fenomena serupa juga terjadi di negara-negara lainnya seperti di Jepang, Tiongkok, ataupun Amerika Serikat (CNBC Indonesia 2019). Fenomena terbentuknya antrean juga dapat dijumpai dalam perilisan iPhone-iPhone sebelumnya. Dalam perilisan iPhone XS dan XS Max, antrean Apple Fans di Singapura tidak hanya melibatkan masyarakat setempat tetapi juga turis dari negara-negara tetangga seperti Indonesia, India, dan Vietnam (Lim 2018). Pembelian terhadap iPhone itu sendiri bukan lagi hanya untuk kebutuhan, melainkan karena ada fanatisme terhadap produk tersebut. Studi yang dilakukan oleh Arruda-Filho et al. (2010) menunjukkan bahwa pembelian iPhone oleh konsumen justru melibatkan faktor-faktor yang tidak terkait dengan aspek fungsional, seperti kesenangan, penerimaan sosial, dan status sosial. Dengan kata lain, konsumsi dalam kasus ini dilakukan untuk kepuasan emosional.

Kecenderungan konsumerisme terhadap produk Apple Inc. selanjutnya dapat ditelaah lebih dalam dengan melihat pola konsumsi dari Apple Fans itu sendiri. Apple Fans mempunyai kecenderungan sebagai pelanggan yang setia. Lebih lanjut, loyalitas ini tidak hanya terbatas pada konsumsi iPhone, tetapi juga produk-produk Apple lainnya seperti Mac, Apple Watch, AirPods, AppleTV, dan sebagainya. Loyalitas ini terbentuk seiring dengan upaya yang dilakukan oleh Apple Inc. dalam membuat sebuah "ekosistem" yang eksklusif. Yang dimaksud "ekosistem" dalam hal ini adalah pembentukan sebuah jaringan yang mengintegrasikan setiap produk yang dijual oleh Apple Inc. (Haselton 2017). Pembentukan jaringan dimulai dengan adanya iPod dan iTunes. Ketika Apple Inc. memproduksi iPhone untuk pertama kalinya pada tahun 2007 , sudah terdapat basis pengguna iPods yang familiar dan terikat dengan software bentukan Apple Inc. seperti iTunes. Dengan demikian, ada dorongan tersendiri bagi pengguna iPod untuk menggunakan iPhone ketimbang ponsel lainnya. Keterikatan lebih lanjut dilakukan dengan peluncuran App Store pada tahun 2008, yang mendorong pengguna untuk membeli aplikasi maupun permainan melalui software besutan Apple Inc. Pembelian musik melalui iTunes hingga pembelian aplikasi dan permainan melalui AppStore tersebut lantas mendorong konsumen untuk tetap menggunakan produk dari Apple Inc.

Upaya pembentukan loyalitas konsumen dilanjutkan melalui peluncuran produk maupun software baru yang terintegrasi satu 
sama lain (Haselton 2017). Sebagai contoh, aplikasi iMessage dan FaceTime dalam iPhone juga dapat dijumpai dalam iPad atau bahkan Mac, sehingga memungkinkan penggunanya untuk melanjutkan percakapan yang awalnya di handphone ke tablet ataupun komputer mereka. Begitu pula dengan Apple Watch, Apple TV, dan perangkat Apple lainnya yang juga terintegrasi satu sama lain (Haselton 2017). Jaringan ekosistem inilah yang kemudian membuat Apple Fans terikat dengan Apple Inc. Keberadaan ekosistem dengan produk yang beragam tersebut bahkan mampu menjadikan Apple sebagai gaya hidup bagi penggemarnya. Apabila dikaitkan dengan argumen teoretis pada bagian sebelumnya, pembentukan ekosistem ini menjadi salah satu pendorong konsumerisme. Pengenalan produkproduk baru dapat dikatakan sebagai upaya dari Apple untuk mengonstruksikan kebutuhan yang ada di masyarakat, sehingga mendorong mereka untuk membeli produk-produk sebelumnya bukan merupakan kebutuhan hidupnya. Tidak hanya itu, peluncuran produk-produk baru yang terintegrasi ini mempunyai peran dalam membentuk loyalitas konsumen Apple Inc. yang kemudian bergeser hingga memunculkan fanatisme tersendiri.

Konsumerisme terhadap iPhone maupun produk-produk Apple lainnya juga didorong dengan aktivitas branding perusahaan yang mengonstruksikan makna tersendiri bagi penggemarnya. Sebagai contoh, di Tiongkok, penggunaan produk Apple dipandang sebagai simbol kekayaan dan kebanggaan (Chiang 2013). Dalam konteks ini, produk Apple dipandang sebagai sesuatu yang mewah dan eksklusif. Adapun makna tersebut makna tersebut tidak terbentuk dengan sendirinya. Apabila diteliti lebih lanjut, Apple Inc. melalui branding yang dilakukannya berusaha untuk mengonstruksikan eksklusivitas dan kemewahan tersebut. Eksklusivitas salah satunya dapat dijumpai dalam pembentukan ekosistem Apple Inc. di paragraf sebelumnya. Tidak hanya itu, eksklusivitas produk-produk Apple Inc. juga dapat dijumpai dalam hal harga. iPhone generasi pertama dijual dengan harga USD 499 dan USD 599 saat pertama kali diluncurkan pada tahun 2007. Harga tersebut lebih tinggi dari kompetitor-kompetitornya pada saat itu seperti BlackBberry 8800 yang dijual dengan harga USD 299 ataupun Samsung BlackJack yang dijual dengan harga USD 199 (Gilbert 2019). Penetapan harga yang cukup tinggi ini secara konsisten dilakukan oleh Apple Inc. sampai saat ini. iPhone 11, sebagai iPhone keluaran terbaru, dijual dengan harga paling rendah USD 699 (Apple Inc. 2019a) atau sekitar 10 juta Rupiah. Sementara itu, iPhone 11 Pro Max, sebagai varian tertinggi dari iPhone 11 dijual dengan harga mencapai 20,5 juta (Apple Inc. 2019b). Harga yang ditetapkan Apple Inc. tersebut cukup tinggi apabila dibandingkan dengan kompetitor-kompetitornya, seperti 
Samsung yang mempunyai banyak lini ponsel dengan harga mulai dari 2,5 juta Rupiah sampai 19 juta Rupiah (Samsung Electronics 2019). Dengan perbedaan tersebut, iPhone diposisikan sebagai barang yang hanya dapat dimiliki oleh kaum menengah ke atas sehingga dapat membentuk konstruksi bahwa iPhone merupakan barang yang mewah dan eksklusif. Dengan kondisi demikian, terdapat anggapan bahwa ketika seseorang membeli sebuah iPhone, orang tersebut telah masuk ke dalam kelas menengah ke atas. Kesan eksklusif dalam iPhone maupun produk Apple Inc. lainnya dipertegas dengan adanya logo unik yakni buah apel yang tergigit. Keberadaan logo ini telah memberikan identitas tersendiri bagi pengguna produk Apple Inc. dan membedakan mereka dengan pengguna ponsel lainnya (Dissanayake dan Amarasuriya 2015). Eksklusivitas inilah yang kemudian menjadi daya tarik dalam masyarakat sehingga mendorong adanya tindakan pembelian sebagai bentuk kebanggaan dan bukan lagi sebagai bentuk pemenuhan kebutuhan.

Konsumerisme terhadap iPhone maupun produk Apple Inc. lainnya mempunyai potensi ancaman yang serius terhadap lingkungan. Sama halnya dengan gawai lainnya, iPhone membutuhkan baterai untuk beroperasi. Sejalan dengan tingginya angka penjualan iPhone di dunia, maka kebutuhan atas baterai juga cenderung meningkat. Kebutuhan atas baterai ini dapat menyebabkan kerusakan lingkungan, salah satunya ditunjukkan dalam aktivitas penambangan grafit sebagai bahan utama dari baterai. Peningkatan intensitas penambangan grafit menyebabkan menipisnya cadangan sumber daya atas material itu sendiri. Lebih lanjut, aktivitas penambangan grafit juga dapat menyebabkan graphite rain yang mencemari udara dan air di daerah sekitarnya (WEF 2015). Selain grafit, produksi baterai juga membutuhkan material-material lainnya seperti kobalt, nikel, dan lithium. Penambangan untuk material-material tersebut telah menyebabkan pencemaran di berbagai belahan dunia, seperti banyaknya debu, asap, air limbah, dan dampak lingkungan lainnya dari penambangan kobalt di Republik Demokratik Kongo; kekurangan air serta adanya tumpahan racun dari penambangan lithium di Amerika Latin; hingga adanya sungai yang tercemar akibat penambangan nikel di Rusia (WEF 2017). Dengan demikian jelas bahwa, peningkatan permintaan terhadap iPhone maupun peranti-peranti teknologi lainnya dapat merusak lingkungan.

Kerusakan lingkungan juga dapat disebabkan dengan adanya limbah elektronik. Berdasarkan analisis Weyler (2019) yang dilansir oleh Greenpeace, rata-rata masa hidup gawai di dunia adalah dua setengah tahun. Hal ini berarti bahwa rata-rata pengguna iPhone cenderung mengganti iPhone yang dimilikinya dengan produk yang 
baru setelah 2,5 tahun masa pemakaian. Adapun kecenderungan tersebut dibarengi dengan kebijakan perusahaan yang secara rutin memberikan pembaruan terhadap produk-produknya. Weyler (2019) menjelaskan bahwa dalam kurun waktu antara 29 Juni 2007 dan 3 November 2017, Apple telah memperkenalkan 14 model iPhone baru. Hal ini berarti bahwa setiap 37 minggu Apple akan melakukan pembaruan terhadap iPhone. Sebagaimana dijelaskan pada bagian sebelumnya, kemunculan produk-produk baru dapat mendorong masyarakat untuk melakukan konsumsi, yakni dengan mengonstruksikan sebuah kebutuhan baru. Tidak hanya itu, perilisan produk baru juga membuat barang yang telah dimiliki sebelumnya sebagai hal yang sudah usang dan tidak relevan. Dengan demikian, dalam setiap pembaruan iPhone yang dilakukan Apple Inc. akan muncul kecenderungan dari penggunanya untuk membeli iPhone yang baru. Proses pembaruan inilah yang kemudian berpotensi memunculkan limbah elektronik yang cukup banyak, mengingat angka penjualan iPhone yang mencapai lebih dari 200 juta unit per tahun.

Kecenderungan penggantian iPhone juga didukung oleh kebijakankebijakan Apple Inc. lainnya. Apple Inc. mempunyai kecenderungan untuk menghentikan dukungan pembaruan software bagi iPhone maupun produk-produknya yang lain setelah 3 tahun dari waktu pertama kali perilisannya (Weyler 2019). Penghentian dukungan pembaruan software ini secara jelas akan menjadikan produk iPhone menjadi tidak relevan dengan hal-hal yang baru sehingga mendorong penggunanya untuk melakukan pembaruan produk. Weyler (2019) juga berargumen bahwa Apple Inc. secara sengaja mempersulit upaya perbaikan terhadap produknya yang rusak, tepatnya dengan merancang sebuah produk dengan suku cadang yang sulit untuk diperbaiki oleh masyarakat awam. Tidak hanya itu, Apple Inc. juga melakukan lobbying untuk menggagalkan rancangan undang-undangan terkait "hak untuk memperbaiki" atau "Fair Repair Act" di Amerika Serikat (Koebler, 2017). Sebagai akibat dari berbagai hambatan tersebut, perbaikan hanya dapat dilakukan melalui toko resmi Apple yang umumnya membutuhkan biaya lebih tinggi apabila dibandingkan dengan perbaikan secara mandiri. Dengan demikian, pembaruan gawai menjadi opsi yang lebih diminati untuk dilakukan bagi pengguna Apple Inc. sehingga dapat menyebabkan konsumerisme hingga munculnya limbah elektronik yang cukup banyak.

Apple Inc. sendiri menyadari bahwa penjualan iPhone yang cukup masif dapat menghasilkan banyak limbah elektronik. Maka dari itu, Apple Inc. melaksanakan program recycling yang diwujudkan salah 
satunya melalui mekanisme trade-in. Trade-in memungkinkan pengguna lama untuk mengganti produk Apple yang dimilikinya dengan potongan harga guna mendapatkan produk yang baru (Apple Inc. 2019). Produk yang didapat dari trade-in ini selanjutnya akan melalui proses recycle oleh robot Daisy. Robot ini merupakan bentuk pengembangan dari Liam, robot yang diciptakan Apple untuk mendaur ulang iPhone. Robot Daisy akan melakukan pemisahan terhadap setiap bagian yang dimiliki iPhone untuk selanjutnya di daur ulang (Moorhead 2018). Pada dasarnya, hal ini merupakan upaya yang baik dalam pengurangan limbah elektronik. Namun, upaya tersebut masih belum cukup untuk mengatasi limbah elektronik yang dihasilkan dari penjualan iPhone. Sampai tahun 2019, hanya ada satu robot Daisy yang dimiliki oleh Apple Inc. di Austin, Texas. Robot ini mempunyai kapasitas untuk mendaur ulang 200 unit iPhone setiap jamnya (Moorhead 2018). Dengan kata lain, dibutuhkan setidaknya 125 robot Daisy yang bekerja dalam waktu 23 jam sehari, 350 hari dalam setahun, untuk mendaur ulang 200 juta unit iPhone. Hal ini berarti bahwa permasalahan limbah elektronik yang dihasilkan Apple Inc. masih menjadi ancaman bagi kondisi lingkungan.

\section{Kesimpulan}

Dengan demikian dapat disimpulkan bahwa konsumerisme terhadap peranti teknologi mengandung ancaman yang serius bagi kelestarian lingkungan. Ancaman tersebut berkaitan dengan eksploitasi sumber daya untuk material yang dibutuhkan dalam proses pembuatan peranti-peranti teknologi tersebut. Eksploitasi sumber daya yang dilakukan melalui proses penambangan dapat menyebabkan menipisnya cadangan sumber daya terkait serta dapat mencemari kondisi lingkungan sekitar. Konsumerisme terhadap peranti teknologi juga mengancam kelestarian lingkungan karena berpotensi menghasilkan banyak sampah elektronik. Kompleksitas permasalahan ini meningkat dengan adanya fakta bahwa konsumerisme terhadap gawai justru didorong oleh aktivitas korporasi sebagai produsen. Korporasi secara masif menciptakan dan memasarkan produknya di berbagai belahan dunia. Aktivitas inilah yang kemudian mendorong terjadinya konsumsi secara terus menerus oleh masyarakat luas. Dalam studi kasus yang penulis angkat, aktivitas korporasi bahkan mampu mendorong terciptanya fanatisme terhadap produk. Tidak hanya itu, studi kasus yang dilakukan penulis juga menunjukkan adanya fakta bahwa korporasi cenderung membuat masa hidup produknya menjadi pendek, di antaranya dengan melakukan berbagai pembaruan produk atau bahkan membatasi upaya perbaikan terhadap produknya yang 
mengalami kerusakan. Langkah daur ulang telah diupayakan, namun upaya tersebut masih belum mampu mengimbangi volume sampah elektronik yang dihasilkan dari aktivitas konsumsi masyarakat dunia. Sebagaimana dicontohkan dalam studi kasus, kapasitas daur ulang yang dilakukan oleh Apple Inc. belum mampu mengimbangi volume iPhone yang dijual oleh perusahaan tersebut setiap tahunnya. Hal ini berarti bahwa ancaman sampah elektronik masih belum mampu diatasi. Maka dari itu, penulis berpendapat bahwa dibutuhkan analisis dan solusi lebih lanjut dalam mengatasi permasalahan yang ditimbulkan dari konsumerisme terhadap gawai. Permasalahan ini menjadi urgensi tersendiri dengan adanya fakta bahwa Apple Inc. bukan satu-satunya perusahaan yang memproduksi gawai. Terdapat perusahaan-perusahaan lainnya seperti Samsung Electronics, Huawei, Oppo, Xiaomi yang masing-masing juga menimbulkan dampak serupa dengan apa yang ditunjukkan penulis dalam tulisan ini. 


\section{Daftar Pustaka}

\section{Buku dan Artikel Jurnal}

Arruda-Filho, E.J., Cabusas, J.A. dan Dholakia, N., 2010. Social behavior and brand devotion among iPhone innovators. International journal of information management, 30(6): 475-480.

Dissanayake, R. and Amarasuriya, T., 2015. "Role of brand identity in developing global brands: A literature based review on case comparison between Apple iPhone vs Samsung smartphone brands", Research journal of business and management, 2(3): 430-440.

McKinnie, T.J., 2017. Sustaining Consumerism. Critical Reflections: A Student Journal on Contemporary Sociological Issues.

Morewedge Carey K, Holzman Leif and Epley Nicholas (2007), "Unfixed Resources: Perceived Costs, Consumption and the Accessible Account Effect”, Journal of Consumer Research, 34: 459-467.

Mumby, Dennis K., 2012. Organizational Communication: A Critical Approach. SAGE Publications.

Rahmawati, A., Soesilowati, E. and Sanjoto, T.B., 2018. "Adolescent Lifestyle of Gadget Users in Kudus City”, Journal of Educational Social Studies, 7(1): 52-60.

Ritzer, George, 2007. "Introduction", dalam The Blackwell Companion of Globalization. Malden: Blackweel Publishing.

Stearns, P.N., 2006. Consumerism in world history: The global transformation of desire. Routledge.

Thomas, S.E. and Wilson, P.R., 2012. "Youth Consumerism and Consumption of Status Products: A Study on the Prevalence of Social Pressure Among Students of Professional Courses". IUP Journal of Business Strategy, 9(2): 44-64.

Thun, Eric, 2008. "The Globalization of Production", dalam Global Political Economy. Oxford: Oxford University Press.

Wilska, T.A., 2003. "Mobile phone use as part of young people's consumption styles". Journal of consumer policy, 26(4): 441463. 


\section{Artikel Berita}

Chiang, Jongwen, 2013. "Why China Loves Apple", CNN, 15 Januari 2013 [Online]. Tersedia dalam: https://edition.cnn. com/2013/01/15/opinion/chiang-apple-china/ [Diakses 20 Oktober 2019].

CNBC Indonesia, 2019. "iPhone 11 Resmi Dijual, Antrean Apple Fanboy Mengular", CNBC Indonesia, 20 September 2019 [Online]. Tersedia dalam: https://www.cnbcindonesia.com/ tech/20190920122322-38-100952/iphone-11-resmi-dijualantrean-apple-fanboy-mengular [Diakses 20 Oktober 2019].

Dunn, J., 2017. "People are holding onto their smartphones longer", Business Insider, 2 Maret [Online]. Tersedia dalam: https:// www.businessinsider.sg/how-long-people-wait-to-upgradephones-chart-2017-3?r=US\&IR=T [Diakses 20 Oktober 2019].

Gilbert, Ben, 2019. It's been over 12 years since the iPhone debuted

- look how primitive the first one seems today, Business Insider, 22 Juli 2019 [Online]. Tersedia dalam: https:// www.businessinsider.sg/first-phone-anniversary-201612/?r=US\&IR=T [Diakses 20 Oktober 2019].

Haselton, Todd, 2017. "Here's why people keep buying Apple products”, Business Insider, 1 Mei 2017 [Onine]. Tersedia dalam: https://www.cnbc.com/2017/05/01/why-peoplekeep-buying-apple-products.html [Diakses 20 Oktober 2019].

Koebler, Jason, 2017. "Apple Is Lobbying Against Your Right to Repair iPhones, New York State Records Confirm”, VICE, 18 Mei 2019 [Online]. Tersedia dalam: https://www.vice.com/ en_us/article/nz85y7/apple-is-lobbying-against-your-rightto-repair-iphones-new-york-state-records-confirm [Diakses 21 Oktober 2019].

Lim, Sean, 2018. "Here's why people queue overnight for the new iPhone XS and XS Max - and it's not only because they're obsessed Apple fans", Business Insider, 21 September 2018 [Online]. Tersedia dalam: https://www.businessinsider.sg/ iphone-xs-max-apple-fans/ [Diakses 20 Oktober 2019].

Lu, T., 2018. Smartphone Users Replace Their Device Every TwentyOne Months, Counterpoint, 13 Oktober [Online]. Tersedia dalam: https://www.counterpointresearch.com/smartphoneusers-replace-their-device-every-twenty-one-months / 
[Diakses 20 Oktober 2019].

Moorhead, Patrick, 2018. "Apple's New iPhone Recycling Robot 'Daisy' Is Impressive, And In Austin”, Forbes, 19 April 2018 [Online]. Tersedia dalam: https://www.forbes.com/sites/ patrickmoorhead/2018/04/19/apples-new-iphone-recyclingrobot-daisy-is-impressive-and-in-austin/\#6f6o79b7f2e4 [Diakses 21 Oktober 2019].

Ponciano, J., 2019. The Largest Technology Companies in 2019: Apple Reigns As Smartphones Slip And Cloud Services Thrive, Forbes, 15 Mei 2019 [Online]. Tersedia dalam: https://www. forbes.com/sites/jonathanponciano/2019/05/15/worldslargest-tech-companies-2019/\#295539b9734f [Diakses 20 Oktober 2019].

Reisinger, D., 2019. "Apple iPhone Sales Tanked at the End of 2018", Fortune, 21 Februari 2019 [Online]. Tersedia dalam: https:// fortune.com/2019/02/21/apple-iphone-sales-2018/ [Diakses 20 Oktober 2019].

\section{Situs dan Artikel Daring}

Apple Inc., 2018. Annual Reports on Form 10-K (2018 10-K) [Online]. Tersedia dalam: https://s2.q4cdn.com/470004039/files/ doc_financials/2018/q4/10-K-2018-(As-Filed).pdf [Diakses 20 Oktober 2019].

Apple Inc., 2015. Annual Reports on Form 10-K (2015 10-K) [Online]. Tersedia dalam: https://s2.q4cdn.com/470004039/files/ doc_financials/2015/annual/2015_Form_10-K_As-filed.pdf [Diakses 20 Oktober 2019].

Apple Inc., 2019. “Apple Trade In” [Online]. Tersedia dalam: https:// www.apple.com/shop/trade-in [Diakses 21 Oktober 2019].

Apple Inc., 2019a. "iPhone 11" [Online]. Tersedia dalam: https:// www.apple.com/shop/buy-iphone/iphone-11/ [Diakses 20 Oktober 2019].

Apple Inc., 2019b. "iPhone 11 Pro" [Online]. Tersedia dalam: https:// www.apple.com/shop/buy-iphone/iphone-11-pro [Diakses 20 Oktober 2019].

Gartner, 2019. Gartner Says Global Smartphone Sales Stalled in 
the Fourth Quarter of 2018 [Online]. Tersedia dalam: https:// www.gartner.com/en/newsroom/press-releases/2019-02-21gartner-says-global-smartphone-sales-stalled-in-the-fourthquart [Diakses 20 Oktober 2019].

Organization Economic Co-operation and Development (OECD), n.d. "Global Value Chains (GVC)" [Online]. Tersedia dalam: http://www.oecd.org/sti/ind/global-value-chains.htm [Diakses 19 Oktober 2019].

Richardson, A. dan Terrell E., 2008. "Apple Computer Inc." [Online]. Tersedia dalam: https://www.loc.gov/rr/business/ businesshistory/April/apple.html [Diakses 20 Oktober 2019].

Samsung Electronics, 2019. "Samsung Smartphones" [Online]. Tersedia dalam: https://www.samsung.com/id/smartphones/ all-smartphones/ [Diakses 20 Oktober 2019].

Weyler, 2019. "It's a Waste World" [Online]. Tersedia dalam: https://www.greenpeace.org/international/story/23747/itsa-waste-world/ [Diakses 21 Oktober 2019].

World Bank, 2018. "More Inclusive Global Value Chains Can Advance Productivity and Growth in Developing Countries" [Online]. Tersedia dalam: http://www.worldbank.org/en/news/pressrelease/2017/07/10/more-inclusive-global-value-chains-canadvance-productivity-and-growth-in-developing-countries [Diakses 19 Oktober 2019].

World Economic Forum, 2015. "How do batteries affect the environment?" [Online]. Tersedia dalam: https://www. weforum.org/agenda/2015/o6/how-do-batteries-affect-theenvironment/[Diakses 21 Oktober 2019].

World Economic Forum, 2017. "Batteries can be part of the fight against climate change - if we do these five things" [Online]. Tersedia dalam: https://www.weforum.org/agenda/2017/11/ battery-batteries-electric-cars-carbon-sustainable-powerenergy/ [Diakses 21 Oktober 2019].

\section{Working Paper}

Orecchia, Carlo and Zoppoli, Pietro, 2007. "Konsumerisme and Environment: Does Consumption Behaviour Affect Environmental Quality?”. CEIS Working Paper No. 261. 


\section{Disertasi, Thesis, dan Skripsi}

Johnson, Katherine; Li, Yang; Phan, Hang; Singer, Jason; and Trinh, Hoang, 2012. "The Innovative Success that is Apple, Inc.". Theses, Dissertations and Capstones. Huntington: Marshall University [Online]. Tersedia dalam: http://mds.marshall. $\mathrm{edu} /$ cgi/viewcontent.cgi? article $=1420 \&$ context $=$ etd [Diakses 20 Oktober 2019]. 